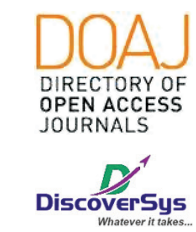

Published by DiscoverSys

\section{Korelasi volume prostat terhadap derajat lower urinary tract symptoms}

\author{
Jufriady Ismy, ${ }^{1 *}$ Sarah Safira, ${ }^{2}$ Iskandar Zakaria ${ }^{3}$
}

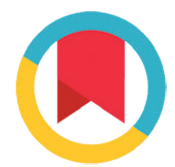

CrossMark

\title{
ABSTRACT
}

Introduction: Benign prostatic hyperplasia is a health problem whose incidence ranks second highest in the field of urology. One of the cause is the more severe the complaint that arises is the heavier prostat volume which can cause the iritative and obstructive symptoms or better known as lower urinary tract symptoms(LUTS) which will be assessed based of international prostate symptoms score (IPSS). This study aims to determine prostate volume correlation with lower urinary tract symptoms severity in RSUD dr. Zainoel Abidin Banda Aceh. Knowledge of the volume of the prostate is important in management of patients with benign prostatic hyperplasia.

Method: This study uses the Cross Sectional design by selecting respondents in accidental sampling with a total of 31 patient. The data obtained were then analyzed by the Spearman test.
Result: The univariat data shows that 18 patient (58.1\%) are in Grade III (31-50 cc) and the most coming patient have LUTS scoring symptoms level on moderate (8-19) are 12 patient (38.7\%) and severe symptoms (20-35) are 17 patient (54.8\%). The results of prostate volume with lower urinary tract symptoms data analysis show that the $p$-value $=$ 0.323 ( $p>0.05)$.

Conclusion: The results of this study indicate that the prostate volume doesn't have correlation with lower urinary tract symptoms severity in patient with benign prostatic hyperplasia in RSUD dr. Zainoel Abidin Banda Aceh.

Keywords: benign prostatic hyperplasia, lower urinary tract symptoms, correlation.

Cite This Article: Ismy, J., Safira, S., Zakaria, I. 2020. Korelasi volume prostat terhadap derajat lower urinary tract symptoms. Intisari Sains Medis 11(1): 281-285. D0I: 10.15562/ism.v11i1.685

\section{ABSTRAK}

Latar Belakang: Benign prostatic hyperplasia (BPH) merupakan masalah kesehatan yang insidensinya menempati urutan kedua tertinggi di bidang urologi. Salah satu penyebab semakin beratnya keluhan yang muncul adalah semakin besarnya volume prostat dan dapat menyebabkan gejala klinis berupa gejala iritatif dan obstruktif atau lebih dikenal dengan lower urinary tract symptoms (LUTS) yang akan dinilai berdasarkan international prostate symptoms score (IPSS). Metode: Penelitian ini bertujuan untuk mengetahui korelasi volume prostat dengan derajat lower urinary tract symptoms di RSUD dr. Zainoel Abidin Banda Aceh. Pengetahuan tentang volume prostat sangat penting dalam menangani pasien-pasien dengan benign prostatic hyperplasia. Studi ini menggunakan desain Cross Sectional dengan memilih responden secara accidental sampling dengan jumlah sebanyak 31 pasien.

Hasil: Data yang didapat kemudian dianalisis dengan uji Spearman. Hasil analisis data univariat menunjukkan bahwa 18 orang pasien $(58,1 \%)$ memiliki volume prostat Grade III (31-50 cc) dan paling banyak pasien yang memiliki skor derajat LUTS sedang (8-19) yaitu sebanyak 12 pasien (38,7\%) dan derajat LUTS berat (20-35) sebanyak 17 pasien (54,8\%). Hasil analisis data volume prostat dengan derajat LUTS menunjukkan bahwa nilai $p$-value $=0,323(p>0,05)$.

Simpulan: Hasil penelitian ini menunjukkan bahwa volume prostat tidak memiliki korelasi dengan derajat LUTS pasien BPH di RSUD dr. Zainoel Abidin Banda Aceh. Kedokteran, Universitas Syiah Kuala-Rumah Sakit Umum Daerah Zainoel Abidin, Banda Aceh, Indonesia

${ }^{*}$ Correspondence to: Jufriady Ismy, Divisi Urologi, Departemen IImu Bedah, Fakultas Kedokteran, Universitas Syiah Kuala-Rumah Sakit Umum Daerah Zainoel Abidin, Banda Aceh, Indonesia

jufriadyismy@unsyiah.ac.id

Diterima: 07-01-2020

Disetujui: 06-03-2020

Diterbitkan: 27-03-2020
Kata kunci: benign prostatic hyperplasia, lower urinary tract symptoms, korelasi.

Cite Pasal Ini: Ismy, J., Safira, S., Zakaria, I. 2020. Korelasi volume prostat terhadap derajat lower urinary tract symptoms. Intisari Sains Medis 11(1): 281-285. D0I: 10.15562/ism.v11i1.685

\section{PENDAHULUAN}

Istilah gejala saluran kemih bagian bawah (lower urinary tract symptoms) mencakup berbagai macam gejala yang luas. Lower Urinary Tract Symptoms (LUTS) dibagi menjadi gejala obstruktif (voiding symptoms) dan iritatif (storage symptoms). ${ }^{1}$
Lower urinary tract symptoms diperkirakan mempengaruhi lebih dari setengah populasi orang dewasa. ${ }^{2}$ Dilaporkan dunia, pada pria berusia lebih dari 40 tahun keatas yang mengalami LUTS dilaporkan lebih dari 50\% kejadiannya disebabkan 
oleh Benign Prostatic Hyperplasia (BPH). ${ }^{3}$ Di Indonesia sendiri angka kejadian LUTS diperkirakan mencapai hingga 5 juta kasus pada pria dengan rata-rata usia 50 tahun atau lebih. Sekitar 2,5 juta kasus yang ada diantaranya datang dengan keluhan gejala saluran kemih bagian bawah (LUTS) yang diakibatkan oleh $\mathrm{BPH} .{ }^{4}$

Benign Prostatic Hyperplasia (BPH) termasuk salah satu masalah urologi tersering yang dialami oleh pria, karena prostat akan berubah dan membesar ukurannya seiring dengan bertambahnya usia. ${ }^{5}$ BPH merupakan kasus tersering kedua di bagian urologi tepat setelah kasus batu saluran kemih. ${ }^{6}$ Di Indonesia sendiri ditemukan 2,5 juta kasus pada pria yang mengalami BPH. ${ }^{4}$ Di Aceh sendiri, khususnya di RSUDZA Banda Aceh menunjukkan angka kejadian BPH yang cukup tinggi yaitu $66,66 \%$ kasus total dari penyakit prostat. ${ }^{7}$

Meskipun BPH tidak menyebabkan kematian, namun penyakit ini akan menimbulkan gejala yang mengganggu dan akan memberi dampak bagi kualitas hidup pasien. ${ }^{8}$ Data dari Kementrian Kesehatan RI tahun 2017, populasi lansia di Indonesia yang diprediksi akan meningkat menjadi $12,9 \%$ pada tahun 2030 dari $8,1 \%$ pada tahun 2015. Pada tahun 2016 jumlah lansia di Aceh mencapai 415.574 jiwa dan akan terus mengalami peningkatan. ${ }^{9}$

Terdapat banyak cara untuk mengukur volume prostat pada penderita BPH. Salah satunya adalah pemeriksaan dengan menggunakan ultrasonografi. Pemeriksaan dengan ultrasonografi dinilai efektif relatif dan lebih murah. Trans rectal ultrasonography (TRUS) telah menjadi standar pemeriksaan dalam mengevaluasi $\mathrm{BPH}$ diberbagai belahan dunia. Namun penggunaannya di negara berkembang jarang dilakukan, mengingat penempatan fasilitas ataupun alat yang belum merata di daerah-daerah yang ada pada Negara berkembang serta sifatnya yang dinilai lebih invasif, maka pemeriksaan yang umum digunakan untuk mengukur volume prostat adalah dengan menggunakan TAUS (trans abdomen ultrasonography) mengingat biayanya yang relatif terjangkau, aman dan tersedia hampir diseluruh rumah sakit. ${ }^{8,10}$

Pada studi kasus yang dilakukan oleh Junaedi dkk. di RSUP Dr. Kariadi Semarang memaparkan bahwa terdapat adanya hubungan yang kuat dimana semakin tinggi skor IPSS maka semakin tinggi pula volume prostatnya. ${ }^{11}$ Namun penelitian lain menyatakan hal yang berbeda, di Afrika telah dilakukan penelitian oleh Ofoha dkk. pada 103 pasien yang mengeluhkan lower urinary tract symptoms yang disebabkan oleh benign prostatic hyperplasia, didapatkan hasil tidak terdapat adanya hubungan yang signifikan antara skor IPSS pada laki-laki di Afrika dengan volume prostatnya. ${ }^{12}$
Hasil tersebut sesuai dengan penelitian yang telah dilakukan oleh Alawad dkk. yang menyatakan hasil penelitian yang dilakukannya menunjukan tidak terdapat adanya hubungan yang signifikan antara volume prostat dengan derajat International Prostate Symptoms Score. ${ }^{13}$

Benign prostatic hyperplasia adalah penyakit yang berhubungan dengan bertambahnya usia, yang biasanya muncul dengan gejala lower urinary tract symptoms dan akan mengganggu kualitas hidup dengan mengingat angka lansia yang akan terus meningkat kedepannya. Penelitian Korelasi volume prostat dengan derajat lower urinary tract symptoms belum pernah dilakukan di Rumah Sakit Umum Daerah dr.Zainoel Abidin (RSUDZA) Banda Aceh serta adanya perbedaan hasil penelitian yang telah dilakukan di berbagai daerah dan berbagai Negara. Sehingga peneliti tertarik untuk melakukan penelitian mengenai korelasi volume prostat dengan derajat lower urinary tract symptoms di RSUDZA Banda Aceh.

\section{METODOLOGI PENELITIAN}

Penelitian ini bersifat analitik dengan menggunakan desain cross-sectional. Penelitian dilakukan di Poliklinik Urologi Rumah Sakit Umum Daerah dr. Zainoel Abidin (RSUDZA) Banda Aceh. Pengambilan data dilakukan pada 09 Oktober 2019 sampai dengan 08 November 2019.

Populasi yang terlibat dalam penelitian ini adalah seluruh pasien benign prostatic hyperplasia dengan gejala lower urinary tract symptoms yang berkunjung ke Poliklinik Urologi dan membawa hasil pemeriksaan USG prostat di Poliklinik Urologi Rumah Sakit Umum Daerah dr. Zainoel Abidin (RSUDZA) Banda Aceh selama periode penelitian dijalankan.

Pengambilan sampel dilakukan dengan teknik non probability sampling dengan Metode accidental sampling. Total sampel yang diperoleh berdasarkan studi pendahuluan dan sesuai dengan konteks penelitian yang dilakukan. Sampel penelitian ini yaitu sebanyak 31 sampel.

Instrumen yang digunakan dalam penelitian adalah lembar pengumpul data, kuesioner International Prostate Symptoms Score (IPSS) dimana berisi 7 pertanyaan dengan menjawab pertanyaan sesuai dengan seberapa sering gejala-gejala tersebut dirasakan, dan hasil USG prostat untuk memastikan volume prostatnya. Adapun skala ukur yang digunakan untuk volume prostat adalah ordinal dan untuk derajat lower urinary tract symptoms digunakan skala ukur ordinal.

Penelitian ini dilakukan dengan analisis data univariat untuk mendeskripsikan masing-masing 
variable dan analisis bivariat untuk mencari korelasi volume prostat dengan derajat lower urinary tract symptoms menggunakan uji Spearman.

\section{HASIL DAN PEMBAHASAN}

Penelitian ini dilakukan pada seluruh pasien benign prostatic hyperplasia yang melakukan pemeriksaan di Rumah Sakit Umum Daerah dr. Zainoel Abidin (RSUDZA) Banda Aceh selama periode penelitian dijalankan. Penelitian ini dilaksanakan mulai tanggal 09 Oktober 2019 hingga 08 November 2019. Pada penelitian ini didapatkan 31 responden yang memenuhi kriteria inklusi menjadi sampel penelitian.

Karakteristik responden pada penelitian ini akan memberikan gambaran distribusi frekuensi usia terhadap volume prostat. Berikut akan disajikan data distribusi karakteristik responden dalam tabel 1.

Berdasarkan Tabel 1 diatas sejalan dengan teori yang menyatakan bahwa benign prostatic hyperplasia $(\mathrm{BPH})$ merupakan penyakit yang presentasinya meningkat seiring dengan peingkatan usia. ${ }^{14} \mathrm{BPH}$ paling sering menyerang pria lanjut usia karena semakin bertambahnya usia maka akan semakin meningkat juga volume prostatnya. ${ }^{15}$ Biasanya mulai menyerang ketika pria menginjak usia 40 tahun kemudian meningkat menjadi $50 \%$ prevalensinya ketika mereka mulai memasuki usia 50 tahun,
$65 \%$ pada usia 60 tahun dan menjadi $80 \%$ pada saat menginjak usia 70 tahun. ${ }^{3,16}$

Berdasarkan hasil uji tabulasi silang pada tabel 2 didapatkan bahwa pasien dengan Grade III (31-50 cc) adalah yang terbanyak yaitu sebanyak 18 orang $(58,1 \%)$ dan 11 orang $(35,5 \%)$ memiliki keluhan skor IPSS dalam kategori berat (20-35).

Ditinjau dari hasil analisis menggunakan uji spearman, didapatkan nilai probabilitas sebesar 0,0323 ( $p>0,05$ ). Hal ini menunjukkan tidak terdapat korelasi antara kedua variabel tersebut, dimana volume prostat tidak berkorelasi dengan derajat lower urinary tract symtoms di RSUDZA Banda Aceh.

Hasil penelitian ini sejalan dengan penelitian yang dilakukan oleh Bassey dkk. yang menggunakan 61 pria sebagai sampel penelitian dan didapatkan hasil bahwa tidak terdapat adanya hubungan yang signifikan antara dejarat skor IPSS dengan volume prostat, sehingga ukuran volume prostat tidak akan menentukan keparahan lower urinary tract symptoms pada pria dengan benign prostatic hyperplasia. ${ }^{17}$ Hasil penelitian ini juga diperkuat dengan penelitian lain yang dilakukan oleh Agrawal dkk. dalam penelitiannya juga menemukan hasil yang serupa yaitu tidak terdapat adanya hubungan yang signifikan secara statistik antara peningkatan volume prostat dengan keparahan derajat skor IPSS, jadi volume prostat tidak harus menjadi satu-satunya hal yang penting yang

Tabel 1 Karakteristik Responden Berdasarkan Usia Terhadap Volume Prostat

\begin{tabular}{|c|c|c|c|c|c|c|c|c|c|c|c|c|}
\hline \multirow[b]{3}{*}{ Usia } & \multicolumn{10}{|c|}{ Volume prostat } & \multirow{3}{*}{$\begin{array}{c}\text { Total } \\
0\end{array}$} & \multirow[b]{3}{*}{ Nilai $p$} \\
\hline & \multicolumn{2}{|c|}{ Grade I } & \multicolumn{2}{|c|}{ Grade II } & \multicolumn{2}{|c|}{ Grade III } & \multicolumn{2}{|c|}{ Grade IV } & \multicolumn{2}{|c|}{ Grade V } & & \\
\hline & $\mathbf{n}$ & $\%$ & $\mathbf{n}$ & $\%$ & $\mathbf{n}$ & $\%$ & $\mathbf{n}$ & $\%$ & $\mathbf{n}$ & $\%$ & & \\
\hline$<40$ tahun & 0 & 0 & 0 & 0 & 0 & 0 & 0 & 0 & 0 & 0 & 0 & \\
\hline 41-50 tahun & 0 & 0 & 2 & 6,5 & 3 & 9,7 & 0 & 0 & 0 & 0 & 5 & \\
\hline 51-60 tahun & 0 & 0 & 0 & 0 & 5 & 16,1 & 0 & 0 & 0 & 0 & 5 & 0,000 \\
\hline 61-70 tahun & 0 & 0 & 0 & 0 & 5 & 16,1 & 5 & 16,1 & 0 & 0 & 10 & \\
\hline$>70$ tahun & 0 & 0 & 0 & 0 & 5 & 16,1 & 0 & 0 & 6 & 19,4 & 11 & \\
\hline
\end{tabular}

Keterangan: $\mathrm{n}=$ frekuensi subjek penelitian, $\%=$ persentase

Tabel 2 Korelasi Volume Prostat dengan Derajat Lower Urinary Tract Symptoms

\begin{tabular}{|c|c|c|c|c|c|c|c|}
\hline \multirow[b]{3}{*}{ Volume prostat } & \multicolumn{6}{|c|}{ Derajat Lower Urinary Tract Symptoms } & \multirow[b]{3}{*}{ Nilai $p$} \\
\hline & \multicolumn{2}{|c|}{ Ringan } & \multicolumn{2}{|c|}{ Sedang } & \multicolumn{2}{|c|}{ Berat } & \\
\hline & $\mathbf{n}$ & $\%$ & $\mathbf{n}$ & $\%$ & $\mathbf{n}$ & $\%$ & \\
\hline Grade I & 0 & 0 & 0 & 0 & 0 & 0 & \\
\hline Grade II & 0 & 0 & 1 & 3,2 & 1 & 3,2 & \\
\hline Grade III & 2 & 6,5 & 5 & 16,1 & 11 & 35,5 & \\
\hline Grade IV & 0 & 0 & 0 & 0 & 5 & 16,1 & 0,323 \\
\hline Grade V & 0 & 0 & 6 & 19,4 & 0 & 0 & \\
\hline
\end{tabular}

Keterangan: $\mathrm{n}=$ frekuensi subjek penelitian, $\%=$ persentase, $\mathrm{p}=$ nilai kemaknaan/signifikan 
perlu dipertimbangkan, sebaiknya harus juga menilai dampak gejala dalam mengobati kasus-kasus yang terdapat pada pasien penderita benign prostatic hyperplasia. ${ }^{18}$

Hasil penelitian ini juga selaras dengan yang dikemukakan di Campbell-Walsh textbook of Urology $11^{\text {th }}$ Edition yang menyatakan dengan jelas bahwa peningkatan volume prostat tidak berkorelasi dengan keparahan derajat lower urinary tract symptoms. ${ }^{1}$

Volume prostat adalah salah satu pemeriksaan yang utama dilakukan ketika ingin mengetahui progesifitas dari bladder outlet obstruction (BOO), volume prostat yang meningkat akan menyebabkan lumen pars prostatika jadi menyempit sehingga aliran urin yang ingin keluar akan terhambat. ${ }^{19}$ Penelitian yang dilakukan oleh, Hossain dkk. ${ }^{20}$ Memperlihatkan tidak hanya volume prostat saja yang dapat memengaruhi beratnya gejala yang dirasakan. Sebaliknya, BOO justru berkorelasi secara signifikan dengan intravesica prostatic protrusion (IPP). IPP merupakan perubahan morfologi yang terjadi karena lobus medius kelenjar prostat mengalami pertumbuhan tampak sebagai bentuk penonjolan prostat yang dimulai dari leher vesika urinaria hingan mencapai ke dalam vesika urinaria sehingga menghambat aliran urin yang akan keluar melalui leher vesica urinaria serta menyebabkan aktivitas pada vesika urinaria menjadi meningkat selama proses berkemih yang akan memunculkan gejala-gejala atau gangguan ketika berkemih atau istilah ini lebih dikenal dengan lower urinary tract symptoms..$^{20,21}$

\section{SIMPULAN}

Berdasarkan penelitian yang telah dilakukan, maka peneliti dapat mengambil kesimpulan bahwa tidak terdapat korelasi antara volume prostat dengan derajat lower urinary tract symtpoms, sehingga ukuran volume prostat tidak akan menentukan keparahan lower urinary tract symptoms pada pria dengan benign prostatic hyperplasia.

\section{KONFLIK KEPENTINGAN}

Penulis menyatakan tidk terdapat konflik kepentingan terkait publikasi dari artikel penelitian ini.

\section{PENDANAAN}

Penelitian ini tidak mendapatkan pendanaan dari pemerintah maupun sector swasta lainyya.

\section{ETIKA DALAM PENELITIAN}

Penelitian ini telah mendapatkan persetujuan dari Komite Etik RSUDZA/Fakultas Kedokteran Universitas Syiah Kuala, seluruh responden dalam penelitian ini telah mendapatkan inform consent dan menandatangani lembar tersebut terkait keikutsertaannya dalam penelitian ini sebelum dilakukannya pengambilan data.

\section{DAFTAR PUSTAKA}

1. Partin AW, Kavoussi LR, Peters CA, Novick AC. CampbellWalsh Urology 11th Edition. USA: Elsevier Inc.; 2015. 546 p.

2. Wang J, Liao L, Liu M, Sumarsono B, Cong M. Epidemiology of lower urinary tract symptoms in a cross-sectional, population-based study. Medicine (Baltimore). 2018;34:1-10.

3. NF Wasserman. Benign Prostatic Hyperplasia: a review and ultrasound classification. Radiol Clin North Am Prostate Gland. 2006;44:687-710.

4. Sutysna H. Tinjauan Anatomi Klinik Pada Pembesaran Kelenjar Prostat. Jurnal UMSU. 2016;3(1):4-8.

5. Filzha A. Gambaran Benigna prostat Hiperplasia. e-Clinic (eCl). 2017;5(2):250-2.

6. Mitterbergera M, Horningera W, Aignerb F, Pinggeraa GM, Steppanb I, Rehdera P, et al. Ultrasound of the prostate. Cancer Imaging. 2010;10(1):40-8.

7. Pratiwi D. Pola penyakit prostat berdasarkan gambaran histopatologi di instalasi patologi anatomi Rumah Sakit Umum Daerah Dr. Zainoel Abidin Banda Aceh. Universitas Syiah Kuala Banda Aceh; 2013.

8. Idowu A, Ademola A, Abimbola O, Tope B, Al. E. Correlation of transrectal and transabodominal ultrasound measurement of transition zone volume with post-operative enucleated adenoma volume in benign prostatic hypertrophy. Pan Afr Med J. 2013;i:1-5.

9. KEMENKES. Badan pusat informasi dan komunikasi. infodatin. Jakarta: KEMENTRIAN KESEHATAN RI; 2017.

10. Foo KT. The role of transabdominal ultrasound in office urology. Proc Singapore Healthc. 2013;22(2):125-30.

11. Junaedi. Korelasi Antara International Prostate Sympstoms Score(IPSS), Volume Prostat dan Pemeriksaan Urodinamik pada Penderita Hiperplasia Prostat di RSUP Dr. Kariadi Semarang. Universitas Diponegoro; 2001.

12. Ofoha CG, Shu'aibu SI, Akpayak IC, Dakum NK, Ramyil VM. Relationship between prostate volume and IPSS In Africa Men with prostate disease. Jos J Med. 2013;9:16-9.

13. Alawad AAM, Elamin SM, Younis FH. Correlation between prostate volume and lower urinary tract symptoms in Sudanese patients with benign prostatic hyperplasia. Basic Res J Med Clin Sci. 2015;4:121-4.

14. Purnomo BB. Dasar - Dasar Urologi. Edisi keti. Jakarta: Sagung Seto; 2012.

15. Sarwar A, Rathore Z, Rathore S, Butt R. Prostatic Diseases Common Cause of Morbidity in Adult Males. Pak J Med Heal Sci. 2016;10:526-9.

16. Boon, Nicholas A, Colledge NR, Walker BR, Hunter JA. Davidson's Principles and Practice of Medicine 20th Edition, International Edition, Churchill Livingstone. 2006;510-1.

17. Bassey IE, Isiwele EM, Eyam SE, Ushie DE, Ani NE. Section: Surgery Correlation of International Prostate Symptom Score with Prostate Volume and Quality of Life in a Screened Population of University Workers Section. Surgery. 2018;5(1):15-7. 
18. Agrawal CS, Chalis PR, Bhandari BB. Correlation of prostate volume with international prostate symptoms score and quality of life in men with benign prostatic hyperplasia. Nepal Med Coll J. 2008;10:104-7.

19. Kok B, Henry H, Keong T, Michael Y, W FS. Comparation of Intravesical Prostatic Protrusion, Prostate Volume and Serum Prostate Specific Antigene in the Evaluation Bladder Outlet Obstruction. Int J Urol. 2006;13:1509-13.

20. Hosain A, Alam A, Habib A, Rashid M, Rahman H, Islam A, et al. Comparisson Between Prostate Volume and Intravesica Prostatic Protrusion in Detecting BOO due to BPH. Bangladesh Med Ress Counc Bull. 2012;38:14-7.
21. Duarsa G, Lesmana R, Mahadewa T. High Serum Prostate Specific Antigen as A Risk Factor for Moderate-Severe Prostate Inflammation in Patient with Benign Prostatic Hyperplasia. Bali Medical Journal. 2015;4(3):148-151. DOI:10.15562/bmj.v4i3.187

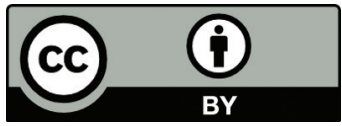

This work is licensed under a Creative Commons Attribution 